\title{
Pembentukan Badan Usaha Milik Desa Di Sumberanyar Pasuruan Untuk Peningkatan Kesejahteraan Masyarakat
}

\author{
Haidar Adam1, Rosa Ristawati ${ }^{2}$, Syifa Ramadhanti ${ }^{3}$, Xavier Nugraha 4 \\ 1,2,3 Fakultas Hukum, Universitas Airlangga \\ ${ }^{3}$ Program Studi Ilmu Hukum, Fakultas Hukum, Universitas Lancang Kuning \\ *e-mail: haidar@fh.unair.ac.id¹, rosarista_ocha@gmail.com ${ }^{2}$, syifa.ramadhanti34@gmail.com³, \\ xavier.nugraha-2015@fh.unair.ac.id
}

\begin{abstract}
To improve welfare in villages, Law No. 6 of 2014 concerning Villages provides an instrument for Villages to conduct business activities through Village-Owned Enterprises. This community service activities aims is to introduce the Village-Owned Enterprises to the community in Sumberanyar Village, Nguling District, Pasuruan Regency to improve welfare in the village. The community service activities begin with the Assessment of Village Problems and Needs, Focus Group Discussions, and ends with the BUMDes Legality. This community service activities shows that the people in Sumberanyar Village, Nguling Subdistrict, Pasuruan Regency have a high enthusiasm for the formation of Village-Owned Enterprises in the village and hope that in the future there will be training related to the management of the Village-Owned Enterprises so that the existing management can carry out its functions and duties properly
\end{abstract}

Keywords: Village-Owned Enterprises, Sumberanyar, Social Welfare

\begin{abstract}
Abstrak
Dalam rangka meningkatakan kesejahteraan di desa-desa, Undang-Undang Nomor 6 Tahun 2014 tentang Desa memberikan sebuah instrument bagi Desa untuk melakukan kegiatan usaha melalui Badan Usaha Milik Desa. Untuk mewujudkan hal tersebut, kegiatan pengabdian ini dilakukan untuk mengenalkan Badan Usaha Milik Desa kepada masyrakat di Desa Sumberanyar, Kecamatan Nguling, Kabupaten Pasuruan dalam rangka meiningkatkan kesejahteraan di desa tersebut. Kegiatan Pengabdian di awali dengan Assesement Masalah dan Kebutuhan Desa, Focus Group Discussion, dan diakhiri dengan Legalitas BUMDes. Dari pengabdian ini menunjukan, bahwa masyrakat di Desa Sumberanyar, Kecamatan Nguling, Kabupaten Pasuruan memiliki antusiasme yang tinggi terhadap pembentukan Badan Usaha Milik Desa di desa tersebut dan berharap kedepannya terdapat pelatihan-pelatihan terkait dengan pengurusan Badan Usaha Milik Desa tersebut agar pengurus-pengurus yang ada dapat menjalankan fungsi dan tugasnya dengan baik
\end{abstract}

Kata kunci: Badan Usaha Milik Desa, Desa Sumberanyar, Kesejahteraan Masyrakat

\section{PENDAHULUAN}

Desa adalah struktur kelembagaan negara yang paling dekat dengan masyarakat dan telah mempunyai peran penting dalam perbaikan nasib hidup rakyat. Proses kekuasan yang sentralistik di masa lalu telah melemahkan berbagai potensi (kemampuan) desa, sehingga berbagai bentuk proses dan bentuk kehidupan masyarakat desa yang dibangun dari akar tradisi setempat secara sistematis hilang.(Indraswari \& Yuhan, 2017)

Penyeragaman desa untuk kepentingan politik ekonomi kekuasaan telah menempatkan rakyat desa dalam posisi marjinal (Cahyono, 2012). Desa tidak lebih dari sekedar imitasi kota dan obyek pemerasan kekuasaan, baik dalam bentuk mobilisasi massa untuk kepentingan politik tertentu ataupun untuk kepentingan program kekuasaan secara sepihak. Sendi-sendi demokrasi di desa nampaknya telah hancur dan digantikan dengan konstruksi politik yang dibangun dari luar desa atau dari atas. Kearifan ekonomi tradisonal desa pun musnah digantikan ekonomi privat yang mengedepankan kapitalisasi dan akumulasi.(Kartini, Mulyawan, \& Yuningsih, 2017)

Paska reformasi, peluang untuk merevitalisasi kekuatan masyarakat desa semakin terbuka dengan adanya pengakuan secara legal bahwa desa merupakan satu kesatuan masyarakat hukum yang berhak untuk mengatur dan mengurus rumah tangganya.(Arizona, 
2010) Meski bersifat normatif, akan tetapi asas ini menjadi strategis terutama bila mengingat bahwa di Indonesia ini setidaknya terdapat lebih kurang 68.000 desa, dan warga negara yang tinggal di wilayah itu mencapai $70 \%$ dari keseluruhan warga negara Indonesia.(Firdaus, 2017) Kehadiran Undang-undang Nomor 6 Tahun 2014 tentang Desa membawa harapan sekaligus kegelisahan baru. Semangat untuk membangun Indonesia melalui pembangunan desa menjadi filosofi penyusunan undang undang tersebut (Achmad Fauzi, 2013). Kucuran dana millaran yang akan diterima desa menjadi pendorong untuk mensejahterakan masyarakat desa. Sudah saatnya desa diberikan kesempatan dan keleluasaan untuk membangun wilayahnya sendiri, untuk mencapai kemajuan dan kesejahteraan, sejajar dengan daerah-daerah perkotaan.(Shohibuddin, 2016)

Dalam rangka memaju kesehateraan desa, salah satu instrument yang disediakan oleh Undang-undang Nomor 6 Tahun 2014 tentang Desa adalah Badan Usaha Milik Desa (selanjutnya disebut BUMDes) (Nina Amelia Novita Sari et al., 2019). Melalui BUMDes ini, diharapkan dapat mendorong gerak ekonomi desa melalu kewirausahaan desa, dimana kewirausahaan desa akan menjadi strategi dalam pengembangan dan pertumbuhan kesejahteraan.(Harmiati \& Zulhakim, 2018) Penggunaan instrument BUMDes untuk melakukan pembangunan ini, sejatinya sesuai dengan teori hukum pembangunan yang disampaikan oleh Mochtar Kusumaadmaja, dimana hukum berperan sebagai suatu kerangka yang berfungsi untuk melakukan pembangunan pada masyrakat. (Berlian Ramadana \& Ribawanto, 1068)

Berkaitan dengan penggunan BUMDes sebagai suatu instrument untuk membangun desa ini, maka juga digunakan untuk melakukan pembangunan di Desa Sumberanyar, Kecamatan Nguling, Kabupaten Pasuruan. Desa Sumberanyar dan beberapa Desa disekitarnya sedang dihadapkan pada permasalahan sengketa tanah dengan pihak Tentara Nasional Indonesia Angkatan laut dimana wilayah Desa tersebut dijadikan latihan tempur. Imbas dari sengketa ini, Masyarakat dari berbagai desa tersebut mengalami kesulitan dalam mengakses beberapa kebutuhan primer seperti listrik, sandang, pangan, dan papan. Untuk itu, pada tahun 2019 ini kegiatan akan lebih difokuskan pada penguatan pada aspek hukum yang berkaitan dengan perekonomian dan kesejahteraan masyarakat sehingga dipilih tema Badan Usaha Milik Desa.

\section{METODE}

Program pendampingan pembentukan BUMDes dilaksanakan selama 5 bulan dari bulan April-September 2019 di Desa Sumberanyar, Kecamatan Nguling, Kabupaten Pasuruan, Provinsi Jawa Timur. Mitra kegiatan PKM ini adalah warga Desa Sumberanyar. Kegiatan dilakukan dengan metode assesement masalah dan kebutuhan desa, focus group discussion, Peningkatan literasi terkait legalitas BUMDes dan pembuatan laporan.(Hendri et al., 2019)

\subsection{Assesement Masalah dan Kebutuhan Desa}

Asessment masalah dan kebutuhan desa: Dilakukan dengan cara datang kedesa berdialog dengan kepala desa, perangkat desa dan tokoh masyarakat untuk mencari potensi dan masalah dalam pengelolaan asset dan sumberdaya di desa Sumberanyar.

\subsection{Focus Group Discussion}

Focus Group Discussion Dilakukan dengan cara mengundang seluruh perangkat desa dan para wakil masyarakat dari seluruh kelompok untuk mencarikan solusi atas masalah desa terutama berkaitan pembentukan BUMDes

\subsection{Peningkatan Literasi Terkait Legalitas BUMDes}

Peningkatan Literasi Terkait Legalitas BUMDesLegalitas BUMDes ini dilakukan dengan memberikan informasi peraturan pembentukan BUMDesa sebagaimana diatur dalam UndangUndang, Peraturan Pemerintah, Peraturan Menteri dan Peraturan Perundang-Undangan lainya. Perangkat desa dan para tokoh masyarakat diharapkan dapat melakukan pengurusan pembentukan BUMDesa dan berkordinasi dengan instansi terkait antara lain kecamatan, 
kabupaten untuk mendapatkan dukungan pelaksanaan program BUMDesa. Selain itu, dalam kegiatan ini juga akan dilakukan review atas peraturan desa yang ada yang terkait dengan permasalahan BUMDes.

\section{HASIL DAN PEMBAHASAN}

Meskipun tim pengmas membatalkan kunjungan pada bulan Agustus, bukan berarti tidak terdapat perkembangan dan kemajuan. Beberapa perwakilan dari Desa Sumberanyar dan tim menjalin kesepakatan tentang penjadwalan ulang penyelenggaraan kegiatan. Disepakati dalam pertemuan tersebut bahwa kegiatan akan dilaksanakan pada Minggu awal bulan September. Selain itu, hal baik yang terjadi adalah pelibatan organisasi masyarakat sipil dalam kegiatan Pengmas seperti Perkumpulan Untuk Peningkatan Usaha Kecil (PUPUK) dalam kegiatan ini. Pihak PUPUK bersedia dalam memberikan materi untuk Sekolah Ekonomi Desa di Desa Sumberanyar. Dengan demikian, hasil yang diharapkan adalah Warga Desa dapat memahami dan menganalisa potensi-potensi yang ada di Desa melalui Sekolah Ekonomi Desa dan Departemen Hukum Tata Negara dapat memberikan pendampingan pada pendirian BUMDESnya melalui Perdes.

Pada tanggal 11 September, dilakukanlah kunjungan ke Desa Sumberanyar oleh Tim dari Departemen HTN dan Tim dari PUPUK. Kegiatan dilakukan di rumah Kepala Desa Sumberanyar. Tim Departemen HTN diwakili oleh Rosa Ristawati dan Haidar Adam dengan dibantu beberapa mahasiswa yaitu Syifa dan Risdiana. Sementara itu, Tim PUPUK diwakili oleh Novarianasari Gameswari, Sendri Lentari, Hari Sugiarto, dan Alief Jhangiz Ahmada. Pertemuan dilakukan kurang lebih selama 4 Jam. Warga yang hadir pada pertemuan tersebut berasal dari berbagai latar belakang yanag terdiri dari Kepala desa, ketua BUMDesa, tokoh masyarakat, Gabungan kelompok tani, perangkat desa, perwakilan desa sekitar dan perwakilan kelompok pemuda. Selanjutnya, diskusi dilakukan dengan mekanisme pembagian kelompok. Kelompok pertama mendiskusikan tentang pemetaan potensi desa beserta permasalahan yang ada. Kelompok kedua mendiskusikan tentang perkembangan situasi di Sumberanyar terkait konflik tanah dan adanya warga yang terserempet peluru. Kelompok pertama difasilitasi oleh Tim dari PUPUK. Sedangkan kelompok kedua difasilitasi oleh Departemen HTN. Hasil diskusi ini, nantinya akan menjadi bahan bagi Departemen HTN dan PUPUK untuk ditindaklanjuti dalam bentuk program.

Hasil dari diskusi tersebut adalah sebagai berikut:

1. Dalam hal yang terkait dengan pemetaan desa, terdapat fakta bahwa di Sumberanyar telah memiliki BUMDesa pada tahun 2019;

2. BUMDesa tersebut bernama "Sumber Anyar Makmur Sejahtera";

3. Modal awal dari BUMDesa berasal dari dana desa sebesar 200 juta;

4. Usaha yang dijalankan adalah fotocopy, toko dan usaha lainnya;

5. Dokumen yang ada pada pengelola BUMDesa adalah Laporan Pembukuan yang pertanggungjawabannya dilakukan selama 6 bulan sekali;

6. Untuk kesekretariatan, BUMDEsa Sumberanyar mendapatkan fasilitas dari Desa;

7. Potensi yang dimiliki Desa adalah sebagian besarnya adalah petani/perkebunan. Sebesar $20 \%$ penduduk Sumber Anyar adalah petani mangga, sebagian lainnya sebagaimana terjelaskan pada bagan dibagian sebelumnya memiliki mata pencaharian yang sangat variatif;

8. Terdapat beberapa permasalahan yang dialami warga yaitu belum selesainya sengketa lahan yang sudah terjadi puluhan tahun;

9. Terdapat pemahaman yang kurang dari para pengurus BUMDesa terhadap regulasi maupun manajemen BUMDEsa; 


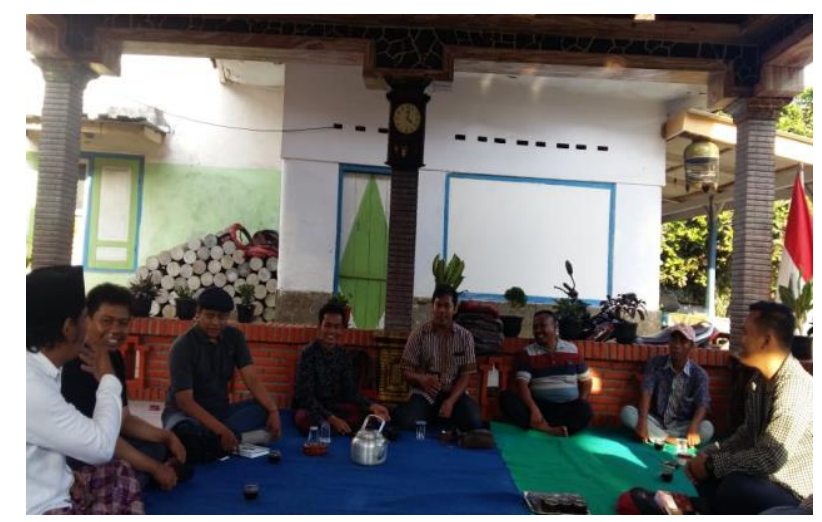

Gambar 1. Diskusi dengan penduduk Desa Sumber Anyar

Untuk selanjutnya, data yang diperoleh diinventarisasi dan didiskusikan untuk ditindaklanjuti. Pada hari Kamis, 14 November, 2019, Departemen HTN melakukan kunjungan ke Desa Sumberanyar untuk menindaklanjuti hasil yang telah didapat pada kunjungan sebelumnya. Kunjungan itu untuk memberikan masukan terkait dengan peraturan desa yang telah dibuat serta memberikan masukan terhadap hal-hal lainnya. Dari pihak Departemen HTN, hadir dosen dibantu dengan beberapa mahasiswa. Kegiatan dimulai pukul 13.00 dan diakhiri pukul 15.30. Berbeda dengan pertemuan sebelumnya yang dilakukan di Rumah Kepala Desa, pertemuan kali ini bertempat di Balai Desa Sumberanyar. Adapun jalannya pertemuan adalah sebagai berikut:

Acara dimulai dengan registrasi yang berlangsung pukul 12.00 sampai dengan 13.00 . Pilihan waktu ini didesain supaya kegiatan bisa berjalan tanpa mengganggu kegiatan ibadah sholat dhuhur. Kebetulan, posisi Balai Desa bersebelahan dengan masjid. Pada pukul 13.00, Acara dimulai oleh pembawa acara dari mahasiswa Fakultas Hukum UNAIR yaitu Aldyan. Pembawa acara membacakan susunan acara yang terdiri dari pembukaan, sambutan dari Kepala Desa, Sambutan dari Ketua Departemen, dan pemberian materi dari Departemen HTN.

Pada saat pembukaan, Kepala Desa Sumber Anyar, Bapak Purwo Eko mengucapkan terimakasih atas kedatangan rombongan dari Departemen Hukum Tata Negara. Ucapan terimakasih dari Kepala Desa juga terarah pada kepercayaan Departemen HTN FH UNAIR yang selama 4 tahun telah bekerjasama dengan Desa Sumberanyar. Secara khusus, Kepala Desa Sumberanyar berterimakasih atas dampingan Departemen terhadap Desa Sumberanyar dalam sengketa tanah yang telah terjadi di dalamnya. Kepala Desa berharap bahwa kerjasama ini dapat terus berlangsung. Setelah itu, Kepala Desa menjelaskan tentang kondisi BUMDEsa yang ada. BUMDEsa Sumberanyar berdiri sejak tahun 2019 berdasarkan Peraturan Desa yang dibuat tahun 2018. Keberadaan BUMDEsa ini mendapatkan modal awal dari desa sebesar 200 juta rupiah. Dana awal tersebut diperuntukkan untuk jenis usaha toko dan photocopy-an. Kemungkinan besar, dana untuk permodalan ini akan semakin bertambah. Pengurus BUMDesa sekarang bukanlah bagian dari pemerintahan desa. Mereka berasal dari warga dan pemuda yang memiliki kapasitas atau setidaknya mau untuk belajar mengelola Bumdesa. Dukungan dari desa tidak hanya sekedar dana, melainkan juga penyediaan kesekretariatan untuk BUMDesa. Harapannya, usaha BUMDEsa yang dirintis dapat berkembang dan menjadikan Desa Sumberanyar lebih sejahtera.

Acara dilanjutkan dengan pemaparan oleh pemateri dari Dosen FH Unair, yakni Ibu Dr. Rosa Ristawati, S.H., LL.M. dan Bapak Haidar Adam, S.H., LL.M. Penyampaian materi pertama disampaikan oleh Ibu Rosa Ristawati. Beliau menyampaikan terkait overview dari Peraturan Desa yang telah dimiliki oleh Desa Sumberanyar. Beliau menyatakan bahwa terdapat beberapa hal penting yang melatarbelakangi pelaksanaan kegiatan pengmas guna pendampingan bagi masyarakat Desa Sumberanyar terkait Bumdes. Dalam hal ini, disampaikan bahwa tahapan pengmas yang diselenggarakan oleh Departemen HTN FH Unair ini meliputi tahapan Assesment yakni tahapan awal terkait pemetaan apa saja kebutuhan dari Masyarakat Desa Sumberanyar 
terkait Bumdes. Pada tahapan awal ini telah dilakukan FGD pada 11 September 2019 antara pihak Desa Sumberanyar dengan Tim Pengmas FH Unair. Kegiatan ini juga melibatkan Perkumpulan Untuk Peningkatan Usaha Kecil dan Menengah (PUPUK) Jawa Timur. PUPUK bersedia untuk memberikan bantuan dalam hal melakukan pemetaan potensi desa sekaligus potensi permasalahannya. Keterlibatan PUPUK dalam kegiatan ini merupakan praktik baik dan nilai tambah bagi Pengmas ini. Dari serangkaian kegiatan penelaahan data dilapangan dan berdasarkan kegiatan kedua yang dilakukan, kesimpulan yang didapat adalah fakta bahwa ternyata Desa Sumberanyar telah memiliki Bumdes yang bernama Bumdes Sumberanyar Makmur Sejahtera. Bumdes ini juga dibentuk berdasarkan Peraturan Desa yang telah disusun oleh Desa Sumberanyar pada awal tahun 2019.

Dengan dibentuknya Perdes tersebut, maka langkah selanjutnya yang dilakukan oleh Tim Pengmas FH Unair adalah melakukan review apakah pengaturan yang telah tertuang dalam Perdes tersebut telah mencakup segala kebutuhan dari penyelenggaraan Bumdes di Desa Sumberanyar. Dari hasil review, beberapa aspek ditemukan perlu untuk dilakukan pembenahan perdes Bumdes. Selain melakukan review atas Perdes Bumdes yang telah dimiliki oleh Desa Sumberanyar, pemateri juga menyampaikan terkait perlunya kolaborasi bersama pihak yang mampu membantu dalam rangka melakukan peningkatan bagi usaha kecil. Salah satu perkumpulan yang dapat membantu pihak Desa Sumberanyar dalam menyelenggarakan dan memberi pengarahan bagi terlaksananya Bumdes yang baik adalah perkumpulan yang bernama PUPUK. PUPUK merupakan Perkumpulan yang bergerak dalam rangka membantu peningkatan usaha kecil. Dengan demikian, Pemerintah Desa Sumberanyar dalam melakukan pengelolaan Bumdes, mampu memperoleh ide, inovasi maupun pengarahan terkait peningkatan Bumdes Sumberanyar Makmur Sejahtera.

Pemateri yang kedua yakni Bapak Haidar Adam, S.H., L.LM. melanjutkan pembahasan terkait review dari Perdes yang telah dibentuk oleh Pemerintah Desa Sumberanyar terkait Bumdes. Beliau menyatakan bahwa diketahui modal awal dari Bumdes Sumberanyar sebesar Rp 200.000.000, - dan seterusnya masih akan bertambah hasilnya. Bumdes di Desa Sumberanyar juga telah memiliki nama dan logo yang mencerminkan filosofi rakyat makmur sejahtera.

Disampaikan pula jenis kegiatan yang dilakukan oleh Bumdes Sumberanyar adalah kegiatan produksi dan pertokoan. Kegiatan produksi tersebut meliputi produksi pembuatan beton. Dalam rangka pembuatan beton tersebut sudah terdapat alat guna melakukan pembuatan beton, namun terdapat permasalahan terkait sengketa lahan yang menyebabkan kendala terhambatnya akses. Selain kegiatan produksi, kegiatan pertokoan juga dilaksanakan oleh Bumdes di Desa Sumberanyar. Pada kegiatan pertokoan ini, dibentuk toko yang menyediakan bahan-bahan untuk kepentingan sehari-hari sekaligus di dalamnya juga terdapat jasa fotocopy. Disampaikan lebih lanjut terkait susunan pengurus Bumdes, bahwa perlu dibentuk pengawas, penasehat dan pengurus Bumdes. Selain itu, dilakukan review terkait isi Perdes yang dalam pengaturan pasalnya perlu diberikan penambahan aturan terkait kepailitan. Dari judul Perdes tentang Bumdes ini, apabila hendak diatur terkait keseluruhan penyelenggaraan Bumdes maka perlu dibentuk judul yang komprehensif dan mencakup materi Perdes.

Dalam rangka pelaksanaan Bumdes, perlu dimanfaatkan hasil asli desa yang nantinya dapat menunjang penyelenggaraan Bumdes. Seperti halnya dikaitkan dengan mata pencaharian masyarakat asli Desa sebagai petani mangga dan adanya sumber ternak yang juga mendukung. Hal tersebutlah yang perlu dimanfaatkan guna peningkatan kesejahteraan masyarakat Desa Sumberanyar. Tidak hanya mengedepankan sektor asli desa, namun juga diharapkan dapat dilakukan inovasi dengan cara melakukan kerjasama dengan pihak-pihak terkait yang mendukung pelaksanaan peningkatan hasil Bumdes. Di penghujung materi disampaikan saran oleh Bapak Haidar Adam bahwa guna mewujudkan penyelenggaraan Bumdes yang baik dapat dilakukan dengan beberapa hal seperti:

1. Melakukan penguatan personal dan kelembagaan dengan melakukan peningkatan kapasitas dan pelatihan bagi kelembagaan Bumdes; 
2. Melakukan benchmarking yakni dengan dilakukannya pembiayaan guna kegiatan studi banding mengunjungi desa-desa lain dan mempelajari karakter dari Bumdes di desa lain. Pengaturan ini telah dicantumkan dalam Perdes Desa Sumberanyar tentang Bumdes;

3. Melakukan koordinasi dan menghubungi Dewan Pemberdayaan Masyarakat Desa guna peningkatan kapasitas desa;

4. Melibatkan dan terlibat dalam komunitas penggerak desa seperti Komunitas PUPUK.

\section{KESIMPULAN}

Dari beberapa hal yang telah diuraikan pada bagian sebelumnya, terdapat beberapa kesimpulan sebagai berikut:

1. Warga Desa Sumberanyar terdiri dari berbagai macam latar belakang dilihat dari perspektif usia, pendidikan, agama, jenis mata pencaharian dll.;

2. Desa Sumberanyar memiliki potensi baik dilihat dari sumber daya manusianya maupun sumber daya alamnya;

3. Sebagian besar warga Desa Sumberanyar adalah petani, dan sebesar $20 \%$ adalah petani mangga;

4. Desa Sumberanyar telah memiliki BUMDEsa sejak tahun 2019 melalui Peraturan Desa Nomor 5 Tahun 2018;

5. Peraturan Desa yang ada, belum cukup merepresentasikan kebutuhan yang ada;

6. Dari sisi teknik perancangan perundangan, banyak kekurangtepatan penyusunan struktur klausula dalam Perdes tentang BUMDesa;

7. Dari sisi majemen, pengurus BUMDEsa banyak yang tidak mengerti mengenai regulasi dan manajemen BUMDesa.

8. Konflik lahan yang terjadi di Desa Sumberanyar menjadi salah satu faktor penghalang akses terhadap peningkatan kesejahteraan.

\section{DAFTAR PUSTAKA}

Arizona, Y. (2010). Dinamika Pengakuan Hukum atas Hak Masyrakat Adat atas Sumber Daya Alam di Indonesia. Jakarta: Epistema Institute.

Bhuvaneswari, K., Geethalakshmi, V., Lakshmanan, A., Srinivasan, R., \& Sekhar, N. U. (2013). The impact of El Nino/ Southern Oscillation on hydrology and rice productivity in the Cauvery Basin, India: Application of the soil and water assessment tool. Weather and Climate Extremes, 2, 39-47.

Brennan, M. A., \& Israel, G. D. (2008). The power of community. Community Development, 39(1), 82-97.

Achmad Fauzi. (2013). Tata Kelola Dana Desa dalam Rangka Implementasi Undang-Undang Nomor 6 Tahun 2014 Tentang Desa di Kabupaten Sidoarjo Achmad. JKMP (Jurnal Kebijakan Dan Manajemen Publik), 1689-1699. https://doi.org/10.1017/CB09781107415324.004

Berlian Ramadana, C., \& Ribawanto, H. (1068). KEBERADAAN BADAN USAHA MILIK DESA (BUMDES) SEBAGAI PENGUATAN EKONOMI DESA (Studi di Desa Landungsari, Kecamatan Dau, Kabupaten Malang). Jurnal Administrasi Publik (JAP), 1(6), 1068-1076.

Cahyono, H. (2012). Arah Perkembangan Demokrasi Di Perdesaan Pasca Orde Baru. Jurnal Masyarakat Indonesia (MI), 38(2), 351-374. Retrieved from http://jmi.ipsk.lipi.go.id/index.php/jmiipsk/article/view/654

Firdaus, E. (2017). Badan Permusyawaratan Desa Dalam Tiga Periode Pemerintahan Di Indonesia. Jurnal Ilmu Hukum, 2(2), 1-21. https://doi.org/10.1017/CB09781107415324.004

Harmiati, \& Zulhakim, A. A. (2018). Eksistensi Badan Usaha Milik Desa (BUMDes) dalam 
Mengembangkan Usaha dan Ekonomi Masyarakat Desa yang Berdaya Saing di Era Masyarakat Ekonomi ASEAN. Jurnal Sekretariat Nasional ASEAN - Indonesia, 2(1), 1-12. Retrieved from http://setnasasean.id/site/uploads/document/journals/file/59b0f03a8a119-14-cluster-ekonomiunihaz.pdf

Hendri, M. I., Widiyantoro, A., Hukum, F., Tanjungpura, U., Tanjungpura, U., \& Tanjungpura, U. (2019). Peningkatan Perilaku Peduli Hukum Dan Lingkungan Melalui Program Kemitraan Masyarakat Peduli Hukum. Dinamisia, 3(1), 1-6.

Indraswari, R. R., \& Yuhan, R. J. (2017). Faktor-Faktor Yang Memengaruhi Penundaan Kelahiran Anak Pertama Di Wilayah Perdesaan Indonesia: Analisis Data Sdki 2012. Jurnal Kependudukan Indonesia, 12(1), 1. https://doi.org/10.14203/jki.v12i1.274

Kartini, D. S., Mulyawan, R., \& Yuningsih, N. Y. (2017). Kapitalisme Pedesaan Di Kawasan Ekonomi Khusus (Kek) Tanjung Lesung Kabupaten Pandeglang Propinsi Banten. CosmoGov, 3(1), 55. https://doi.org/10.24198/cosmogov.v3i1.12636

Shohibuddin, M. (2016). Peluang dan Tantangan Undang-undang Desa dalam Upaya Demokratisasi Tata Kelola Sumber Daya Alam Desa: Perspektif Agraria Kritis. MASYARAKAT: Jurnal Sosiologi, 21(1), 1-33. https://doi.org/10.7454/mjs.v21i1.5021

Sari, N.A.N, Tambunan. E, Felany. P.I, Nugraha.X (2019). Implikasi Penafsiran Hak Menguasai Negara Oleh Mahkamah Konstitusi Terhadap Politik Hukum Agraria Pada Pulau-Pulau Kecil $\begin{array}{lllll}\text { Di Indonesia. UPH Law } & \text { Review, 170:202. }\end{array}$ https://doi.org/10.23126/cosmogov.v4i2.1678 